\section{A Durable, Lightweight Structure for Conducting Field Shading Experiments}

\author{
D.S. NeSmith ${ }^{1}$, P.L. Raymer ${ }^{2}$, M.S.S. Rao ${ }^{2}$, and D.C. Bridges ${ }^{2}$ \\ Georgia Station, Griffin, GA 30223
}

Additional index words. photosynthetically active radiation

Abstract. A low-cost field shading structure was developed that offers durability and simplicity. The quonset-type structure uses readily available materials, including polyvinyl chloride pipe, construction-grade reinforcing bars, nylon rope, and commercial shade fabric. The total cost for a $3.0 \times 6.0 \times 2.4-\mathrm{m}$ (width/length/height) structure that provided $47 \%$ shade was $\$ \mathbf{8 8 . 0 0}$. The structure offers substantial flexibility in terms of size and degree of shading without significantly altering design. The structure was durable under a wide range of weather conditions, and the design allowed sufficient air movement to prevent a stagnant air layer from developing over the crop.

Shading often is used in experiments to provide variable levels of photosynthetically active radiation (PAR) incident upon crops. Means of establishing a shaded area vary; in field situations, a frame typically is covered with commercial shade fabric. Reports on shade structures (Brazenor, 1986; Bucklin, 1987) include elaborate designs for commercial industries. Details of construction and cost for simpler, inexpensive structures are seldom reported in the literature; hence, scientists are often forced to create their own designs through trial and error. For field research purposes, a shading structure that is simple, cheap, and durable is desirable for reducing PAR while- minimizing confounding effects. We describe a field shading structure meeting these criteria.

The shading structure was constructed using readily available materials that included commercial shade fabric and polyvinyl chloride (PVC) pipe (Fig. 1). The frame consisted of 6.2-m lengths of 25.4-mm (inside diameter) PVC pipe (schedule 40) bent to form arches with a base width of $3.0 \mathrm{~m}$ and

Received for publication 9 Mar. 1992. Accepted for publication 23 July 1992. A contribution of the Univ. of Georgia Agr. Expt. Stas., Georgia Station, Griffin. This research was supported by state and Hatch Act funds allocated to the Georgia Agr. Expt. Stas. The cost of publishing this paper was defrayed in part by the payment of page charges. Under postal regulations, this paper therefore must be hereby marked advertisement solely to indicate this fact.

'Dept. of Horticulture.

${ }^{2}$ Dept. of Agronomy. a peak height of $2.4 \mathrm{~m}$. An individual arch was held in place by sliding each end of the PVC over a 600 -mm length of 12.7-mm-diameter solid steel rod (construction-grade reinforcing bar) that was driven in the soil to a depth of $300 \mathrm{~mm}$ (Fig. 2). Five arches spaced $1.5 \mathrm{~m}$ apart for an individual structure provided a covered plot area $6.0 \times 3.0$
${ }^{2}$ Purchased from Progress Growers Supply, Canton, Ga. plot during Mar. 1992.

${ }^{2}$ Soil temperature at a depth of 3 to $4 \mathrm{~cm}$. m (length/width). Heavy-duty, 6.3-mm-diameter nylon rope was tied to a metal stake inserted into the soil $1.5 \mathrm{~m}$ beyond the end arch. This rope was looped tightly over the peak of each arch, and then the other end was tied to a metal stake $1.5 \mathrm{~m}$ beyond the other end arch. The rope provided a unified, stable structure.

Custom-cut commercial shade fabric (with seams and grommets), available in a range of light-transmitting levels, covered the frame. The $5.5 \times 7.4-\mathrm{m}, 47 \%$ shade fabric was draped over the PVC arches and held in place, much like a tent, by tying it with nylon rope along the sides to steel stakes in the ground.

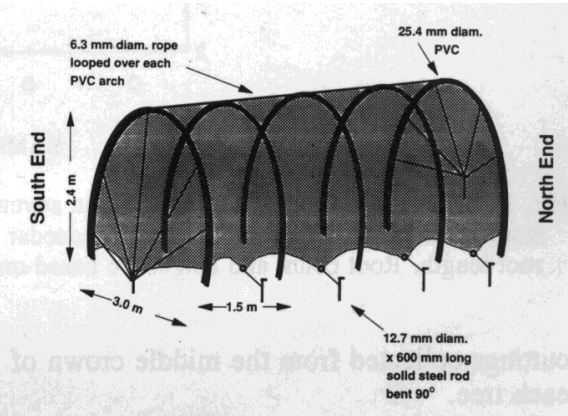

Fig. 1. Schematic diagram of a quonset-type shade structure.

Table 1. Materials and cost for a $3.0 \times 6.0 \times 2.4-\mathrm{m}$ (width/length/height) shading structure.

\begin{tabular}{|c|c|c|}
\hline Quantity & Material & Cost (\$) \\
\hline 5 & Schedule 40 PVC pipe, 25.4-mm diam, $6.2 \mathrm{~m}$ long & 20 \\
\hline 1 & Custom-cut shade fabric ${ }^{2}, 5.5 \times 7.4 \mathrm{~m}$ & 60 \\
\hline 10 & Solid steel rod $(12.7 \times 600 \mathrm{~mm})$ to anchor arch bases & 3 \\
\hline 10 & $\begin{array}{l}\text { Solid steel rod }(12.7 \times 600 \mathrm{~mm}) \text { with } 90^{\circ} \text { bend } 150 \mathrm{~mm} \text { from } \\
\text { one end to secure rope and shade fabric }\end{array}$ & 3 \\
\hline 1 & Nylon rope $(30 \mathrm{~m}$ long $\times 6.3 \mathrm{~mm}$ diam $)$ & 2 \\
\hline Total & & 88 \\
\hline
\end{tabular}

Table 2. A typical week of daily weather data from a plot in full sun and from an adjacent shaded

\begin{tabular}{|c|c|c|c|c|c|c|c|c|}
\hline \multirow[b]{3}{*}{ Date (Mảrch) } & \multirow{2}{*}{\multicolumn{2}{|c|}{$\begin{array}{c}\text { Mean }^{2} \\
\text { soil temp }\left({ }^{\circ} \mathrm{C}\right)\end{array}$}} & \multicolumn{4}{|c|}{ Air temp $\left({ }^{\circ} \mathrm{C}\right)$} & \multirow{2}{*}{\multicolumn{2}{|c|}{$\begin{array}{c}\text { PAR } \\
\left(\mathrm{mol} \cdot \mathrm{m}^{-2} \cdot \mathrm{day}^{-1}\right)\end{array}$}} \\
\hline & & & \multicolumn{2}{|c|}{ Minimum $^{y}$} & \multicolumn{2}{|c|}{ Maximum } & & \\
\hline & $\overline{\text { Sun }}$ & $\overline{\text { Shade }}$ & Sun & $\overline{\text { Shade }}$ & Sun & Shade & Sun & Shade \\
\hline 5 & 10.4 & 10.5 & 3.2 & 3.8 & 26.6 & 24.2 & 31.6 & 14.9 \\
\hline 6 & 12.1 & 12.0 & 10.3 & 11.4 & 26.9 & 23.6 & 26.8 & 13.1 \\
\hline 7 & 11.8 & 12.0 & 9.0 & 9.6 & 17.7 & 16.0 & 8.1 & 4.0 \\
\hline 8 & 13.7 & 16.2 & 12.2 & 12.7 & 23.1 & 21.7 & 15.8 & 7.8 \\
\hline 9 & 13.7 & 14.0 & 9.0 & 10.0 & 25.8 & 24.7 & 32.7 & 16.2 \\
\hline 10 & 12.4 & 13.1 & 4.4 & 5.3 & 24.5 & 23.3 & 35.8 & 18.0 \\
\hline 11 & 12.2 & 12.9 & 6.3 & 7.3 & 25.2 & 22.0 & 31.8 & 15.7 \\
\hline
\end{tabular}

yAir temperatures just above the canola (Brassica rapus L.) canopy. 


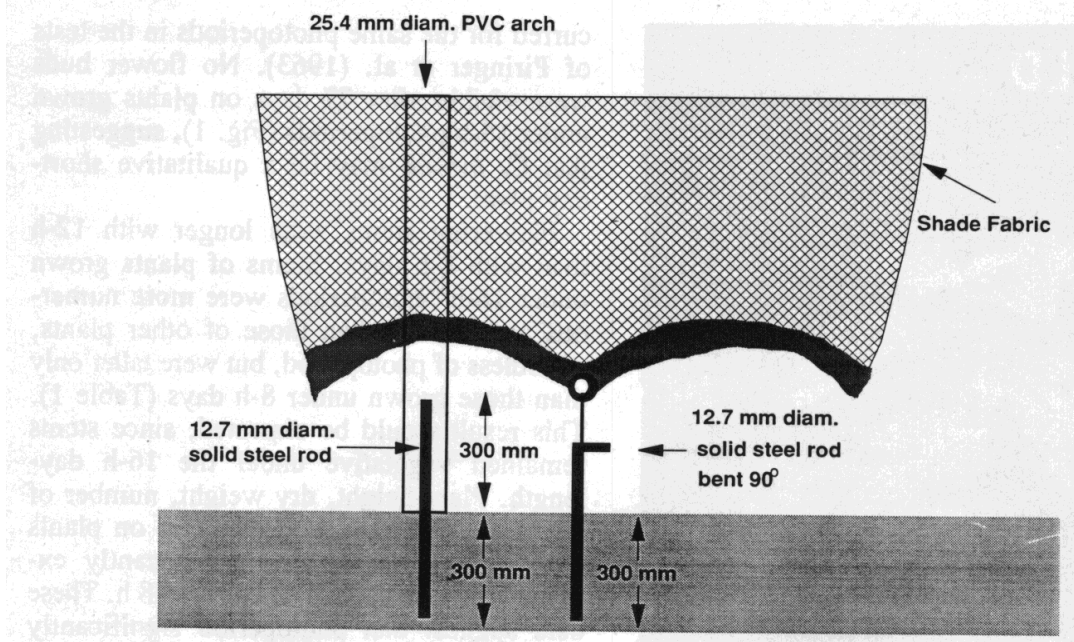

Fig. 2. Schematic diagram of PVC and shade fabric anchoring.

On the ends, additional ropes were used to tie the shade cloth to the stake that had been driven in the ground for the main rope that connected the arches. The shade fabric was not physically attached to the PVC arches. The structures were erected with the long axis in a north-south direction to minimize the distance needed between structures to prevent mutual shading by adjacent units. A separate section of cloth was draped over the arch on the south end to reduce direct solar radiation into the tunnel. The cost of materials for a $3.0 \times 6.0 \times 2.4-\mathrm{m}$ (width/length/ height) structure was less than $\$ 100$ (Table 1). There is substantial flexibility in structure size (by changing arch length, number, or spacing) and degree of shading (by selecting different percent shade fabric) without significant alterations in design.

The structure has proved to be extremely durable; it withstood high winds and rain without collapsing. Our experiment was conducted during winter, and we experienced a rare snowfall of 0.15 to $0.18 \mathrm{~m}$. The shading structures collapsed under the snow load, but as soon as the snow melted the structures sprang back into place and required minimal adjustment. We attribute this flexibility of the structure to the rope that connected the arches as opposed to a more rigid support beam, such as wood.

The structure allowed sufficient air movement to prevent a stagnant air layer from developing over the crop. We placed drip irrigation in our plots to ensure similar soil moisture regimes between covered and uncovered plots, and we equipped a shaded and unshaded plot with PAR and temperature sensors. Daily weather data for a typical week revealed that while PAR differed, soil and air temperatures were similar in a shaded and an unshaded plot (Table 2).

\section{Literature Cited}

Brazenor, W.J. 1986. Design and construction aspects of an agricultural shadecloth structureThe evolution of a system. Proc. Conf. Agr. Eng., Adelaide, Australia, 24-28 Aug. Inst. Eng., Barton, ACT, Australia. p. 12-14.

Bucklin, R.A. 1987. Design of shade structures for plant production. Amer. Soc. Agr. Eng., Paper 87-4060. 